\title{
PERSONIFYING PUBLIC HOUSING ESTATES: EVIDENCE FROM SINGAPORE
}

\section{MUHAMMAD FAISHAL IBRAHIM and YEN PENG ONG National University of Singapore}

\begin{abstract}
Adopting the concept of brand personality, this paper aims to determine the personalities of three public housing estates in Singapore, specifically Jurong East, Pasir Ris and Sengkang housing estates. These three housing estates have distinctive personalities, but also share certain traits. This research provides an avenue for town planners, town councillors, as well as estate managers to measure and position the brand personalities of their housing estates, as well as meeting the needs of the residents living in the housing estates.
\end{abstract}

Keywords: Public housing estates, personality, Singapore.

\section{INTRODUCTION}

Brand personality is the set of human characteristics associated with a brand (Aaker, 1997) and can be considered as one possible perspective for a better understanding of the abstract nature of brand image. Traditionally, practitioners as well as researchers attempted to measure brand personality by either using ad-hoc scales or human personality scales. The ad-hoc measurement scales are often chosen arbitrarily, which casts doubt on the scale's reliability and validity (Aaker, 1997). In addition, brand personality based on human personality scales has not been validated in the context of brands (Bellenger et al., 1976; Kassarjian, 1971). These limitations saw Aaker (1997) develop a theoretical framework of brand personality constructs, by determining the number and nature of dimensions of brand personality. This marks the introduction of a reliable, valid and generalizable scale to measure brand personality.

As a set of human characteristics show common patterns of human personality, this concept focuses on the way in which a consumer perceives a brand through dimensions that typically capture a person's personality (Batra et al., 1993). In contrast to "product-related attributes", which tend to serve a utilitarian function for consumers, brand personality tends to serve a symbolic (Siguaw et al., 1999) or self-expressive function, which gives the consumer issues to relate to which are vivid, alive, and more complete than that conveyed by generic offerings (Siguaw et al., 1999). 
Past research has shown that consumers have no difficulty in personifying retail stores, products and brands. Specifically, consumers can attach personality traits to these retail stores, products and brands (Malhotra, 1981; Plummer, 1984; Aaker, 1997) and can distinguish brands as if they were human characters (Plummer 1984; Alt and Stone, 1988), both positively and negatively (Triplett, 1994).

Using the concept of brand personality, this paper attempts to determine the personalities of public housing estates in Singapore. The authors hope that this will provide another dimension to housing research in the area of public housing development.

\section{The value of brand personality}

Consumers seek brands with personalities that are congruent with either their own or sought after ideal personalities. The greater the congruity between the human characteristics which consistently and distinctively describe an individual's actual or ideal self, and those that describe a brand, the greater the preference for the brand (Sirgy, 1982). This process adopts the idea that consumers use a brand's personality to help define, both for themselves and for others, their sense of self (Belk, 1988), an ideal self, or specific dimensions of self.

A well-established brand personality will result in increased preference and usage (Sirgy, 1982), higher emotional ties to the brand, trust and loyalty (Fournier, 1998). Brand loyalty and equity are driven by brands that have a strong and charismatic personality (Aaker, 1996). A distinctive, robust, desirable and constant personality will successfully differentiate a brand (Lannon, 1993).

Consumers also perceive the brand as a partner in a relationship and brand personality as the set of traits belonging to this partner (Fournier, 1994, 1998). Thus, consumers interact with brands (Lannon, 1993) just like in a relationship. In addition, brand personalities like human personalities can grow and evolve over time.

Research on person-object relationships with a range of consumer goods reveal that people assign human characteristics to goods (Belk, 1988; Rook, 1985); most notable among these goods are tools, food, drink, clothing, weaponry and household technologies. A considerable amount of research has been directed to determining the brand personalities of consumer goods. However, apart from retail stores, little work has been directed toward determining brand personalities of real estate, although it is made up of many components such as buildings, infrastructure, services, experiences and perceptions, all of which are capable of been associated with a person.

Recent work in the USA by Siguaw et al. (1999) was one of the first attempts to measure the brand personality of real estate via restaurants, applying the dimensions 
of brand personality developed by Aaker (1997) to measure the personalities of nine restaurants, representing three restaurant segments: quick service, causal dining and upscale dining. The study identified the brand personality of the nine restaurants and the extent the brand personality differs across the different categories. This initial study provided empirical evidence regarding the extent to which restaurants can establish clear and distinct brand personalities in the minds of consumers.

A housing estate comprises buildings, infrastructure and amenities that are capable of being associated with a person. In addition, a person's experiences of living and interacting within a housing estate will enable the person to form perceptions about the personality of the housing estate. From the perspectives of the town planners, property developers and estate managers, it is worthwhile to examine and understand the brand personalities of housing estates as part of the development and positioning strategy of these housing estates. With insights to the personality of a housing estate, property developers, town planners and estate managers will be able to implement the necessary plans and actions to influence the character of the estate, as well as draw residents who are attracted to the specific personality of the housing estate. From the buyer's perspective, a housing estate which possesses positive personality traits will likely be highly demanded, which may be translated into higher selling price. In addition, a prospective buyer would likely be inclined to purchase a property within a housing estate which possesses personality traits that are congruent to his/her personality. The above justifies the need for more research in brand personality within the real estate market, in this case, public housing estate.

\section{Measuring brand personality}

Before Aaker (1997), there was no formal brand personality scale used to measure brand personality. Instead, researchers relied on measurement scales that tended to be ad hoc (adjective checklists, photo-shots, symbolic analogy) or taken directly from personality psychology. These measurement scales tended to be theoretical in nature and were developed for the purposes of a specific study. As a result, key traits could be missing from such scales. Furthermore, the traits that were selected were chosen arbitrarily, a compromise between strict adherence to a cut-off criterion and exercise of personal judgment (Wells et al., 1957), which casts doubt on the scales' reliability and validity (Aaker, 1997)

The second type of brand personality scales that are based on human personality scales are taken directly from personality psychology. They are more theoretical in nature and the applications of these to marketing settings have appeared only recently (Aaker, 1997; Caprara et al., 1998). For a complete review of these studies, see Digman (1990) and Aaker (1997). It is still questioned, however, whether the personality traits taken from personality psychology can be applied to brands (Caprara et al., 1998). 
Table 1: Brand personality dimensions

\begin{tabular}{|l|l|l|l|l|}
\hline Competence & Sincerity & Excitement & Sophistication & Ruggedness \\
\hline Reliable & Down-to-earth & Daring & Upper-class & Outdoorsy \\
Hardworking & Family-oriented & Trendy & Glamorous & Masculine \\
Secure & Small town & Exciting & Good-looking & Western \\
Intelligent & Honest & Spirited & Charming & Tough \\
Technical & Sincere & Cool & Feminine & Rugged \\
Corporate & Real & Young & Smooth & \\
Successful & Wholesome & Imaginative & & \\
Leader & Original & Unique & & \\
Confident & Cheerful & Up-to-date & & \\
& Sentimental & Independent & & \\
& Friendly & Contemporary & & \\
\end{tabular}

Source: Aaker (1997)

Aaker's (1997) theoretical framework of the brand personality represented by the 42-item brand personality scale as shown in Table 1 has been proven to be reliable, valid and generalizable. Using Aaker's (1997) 42-item brand personality scale, this paper attempts to determine the brand personalities of three public housing estates in Singapore (see Figure 1). Specifically, the brand personalities of Jurong East, Pasir Ris and Sengkang housing estates, each of which were built in a different time period, the 1980s, early 1990s and late 1990s respectively. The extent to which the personalities of these three housing estates differ will also be determined.

\section{RESEARCH METHODOLOGY}

The research strategy adopted in this study is the sequential mixed method, which comprises both qualitative and quantitative research. This is a form of methodological triangulation (Tashakkori and Teddlie, 1998) which should enhance the internal validity of the study. The qualitative research was carried out at the initial stage of the research followed by the quantitative phase.

\section{Qualitative research phase}

The exploratory nature of the investigation into a respondent's perception of public housing, in terms of personality traits, necessitated the implementation of in-depth interviews with a number of respondents before undertaking the quantitative research. The objective of the in-depth interviews was to determine the ability of respondents to come up with personality traits in order to describe the housing estates and at the same time, to draw up an inventory of possible personality traits when public housing is described as a person. 


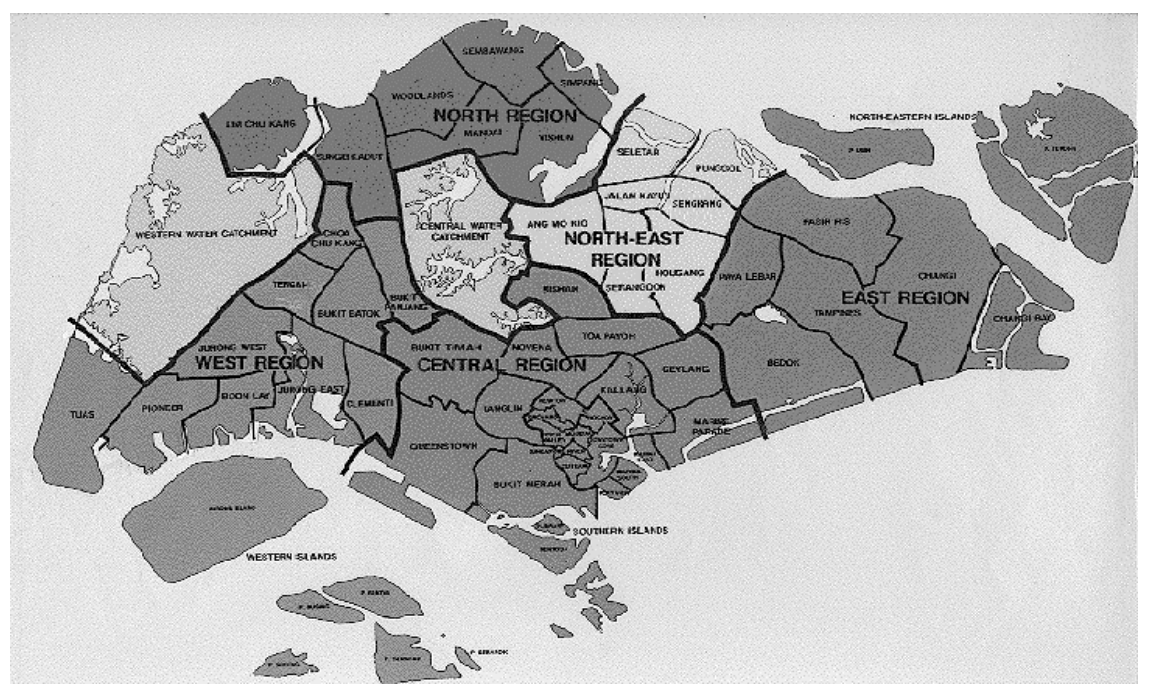

Source: URA, 2002

Walker (1985) suggests that a sample size of between 20 to 40 in-depth interviews is necessary for qualitative studies which are undertaken prior to quantitative studies. 30 residents from Woodlands New Town were selected by the interchange intercept approach (Ibrahim and McGoldrick, 2003) at the bus interchange of Woodland Regional Centre. Specifically, the respondents were asked to identify and describe the personality traits that came to their mind when thinking about public housing estates as persons.

\section{Quantitative research phase}

The inventory of traits obtained during the qualitative phase supported and confirmed Aaker (1997) brand personality scale, and were used in the survey questionnaire for the quantitative research phase. The survey was conducted by way of personal, door-to-door interview with a sample size of 302 . The 302 residents were selected through a multistage sampling procedure. Based on Singapore's planning demarcations of central area, regional centres, towns and neighborhoods, we formed five large clusters of regions, namely, the Central, Northeastern, Northern, Eastern and Western regions. Using a simple lottery method, the Northern region was randomly selected. The Northern region was then disintegrated into seven clusters of towns, namely, Lim Chu Kang, Sungei Kadut, Woodlands, Mandai, Yishun, Simpang and Sembawang. From this, one town (Woodlands) was randomly selected by the simple lottery method. Within the Woodlands New Town, stratified random sampling of public and private 
housings was carried out. Upon the stratification, blocks of public and private housings were randomly selected. Following this, households within the chosen blocks were randomly selected.

The surveys were conducted on weekdays and weekends throughout the whole day, over a period of two months, to ensure that respondents of different demographics are included. A pilot survey of 20 respondents was conducted prior to the actual survey to determine the best format for the questionnaire. The survey sought to measure the brand personality of the three housing estates based on the brand personality scale developed by Aaker (1997). Using a Likert scale, these personality traits were operationalized on a five-point scale, 1 for "strongly disagree", 2 for "disagree", 3 for "neutral", 4 for "agree" and 5 for "strongly agree". The order of the personality traits of the three housing estates presented in the questionnaire was rotated to avoid bias.

The Statistical Package for Social Sciences (SPSS Version 11) was used to process the survey results. Three analytical techniques were adopted for the data analysis; descriptive statistics (mean), a multivariate analysis via factor analysis (principal component) and based on the results of factor analysis, a weighted factor rating (WFR) (Ibrahim, 2002), which transforms the factor loadings of the variables in each factor into a weighted mean rating of each factor, was calculated.

\section{The study areas}

\section{Jurong East Housing Estate}

The Jurong East housing estate was first developed in 1980 (see Figure 2). It is located within the Jurong area, the first industrial estate in Singapore. It covers some 380 hectares of land with 43 percent occupied for residential use. There are some 22,600 units of flats in Jurong East Estate, of which the majority of the flats were constructed in the 1980s. Located in the Western part of Singapore, it is central to the Western Region's catchment of population and employment. The area is well served by the Pan- Island and Ayer Rajah Expressways and near to the Second Causeway to Malaysia. Its Mass Rapid Transit (MRT) interchange connects the East-West line to the North-South line.

\section{Pasir Ris Housing Estate}

The Pasir Ris housing estate, which covers an area of 1,533 hectares of land is located within the Eastern region of Singapore (see Figure 3). It was first developed in 1990 and there are about 27,500 units of flats in Pasir Ris housing estate. The majority of the flats were constructed from 1990 to 1995 . Being located near the coast, as well as being near many holiday resorts and chalets, Pasir Ris town possesses a resort ambience. The recreational environment with parks and other landscaped areas has generated leisure activities including cycling and water sports within the town. It is easily accessible with a bus interchange and East-West MRT line terminating at Pasir Ris Central. 
Figure 2: Jurong East public housing estate

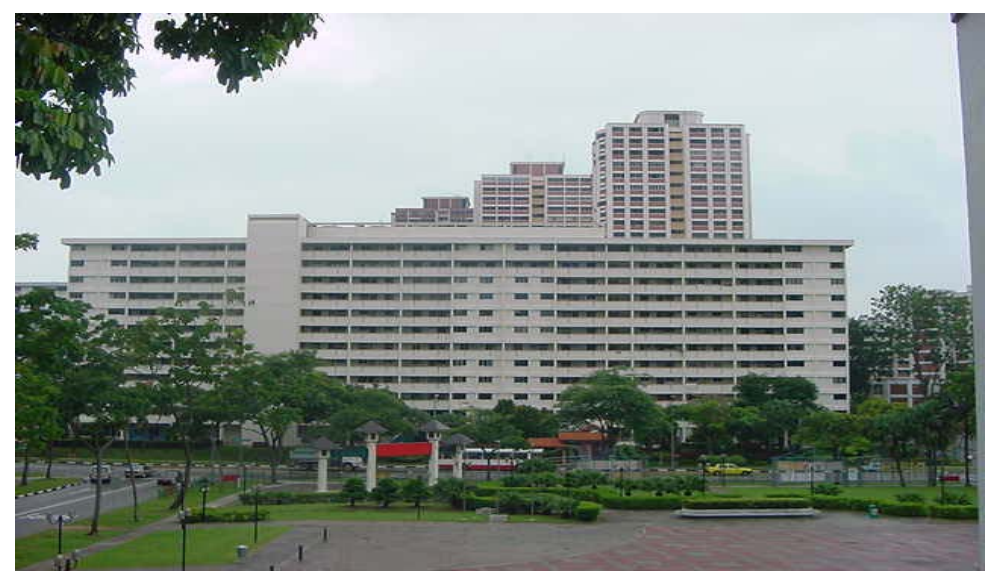

Figure 3: Pasir Ris public housing estate

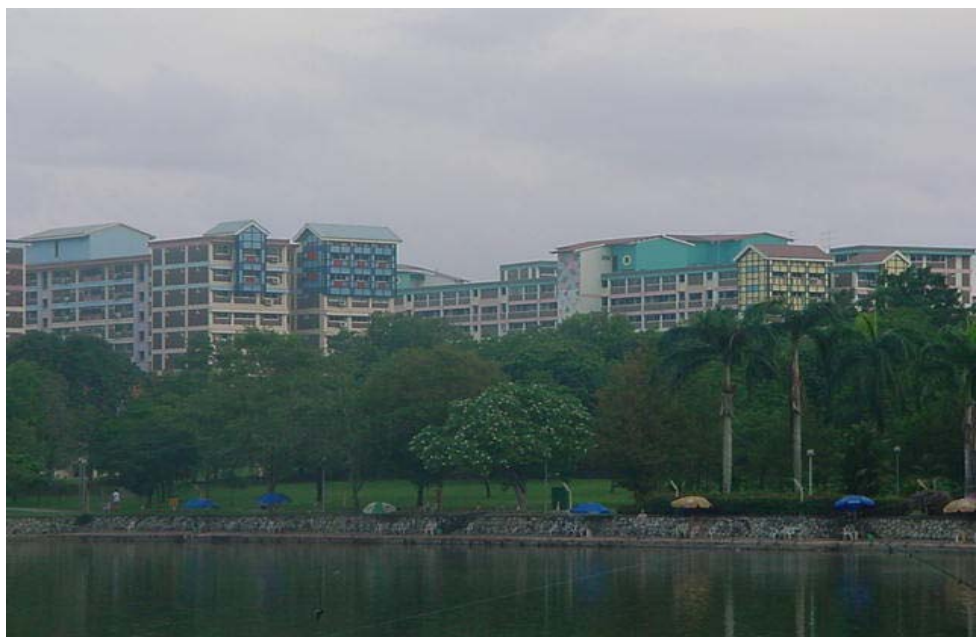

\section{Sengkang Housing Estate}

The Sengkang housing estate was developed in the late 1990s (see Figure 4). It is located within the Northeast region of Singapore. It has the advantage of having some of the latest design and facilities. There are more than 25,000 units of flats and it is expected to have 95,000 units of flats when fully completed. It is accessible via the Central and Tampines Expressways, as well as the Sengkang 
MRT station along the North-East MRT line, which has been in operation since the second half of 2003 .

\section{Figure 4: Sengkang public housing estate}

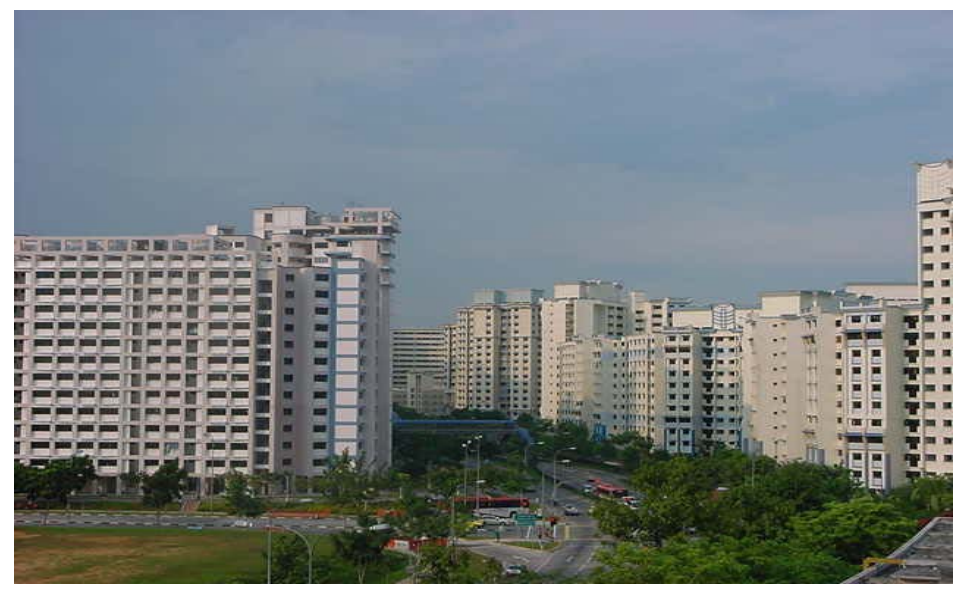

\section{Data analysis: qualitative research phase}

The in-depth interviews during the qualitative research phase contained rich descriptive data that was important in supporting and confirming the theoretical and conceptual framework of the research based on Aaker (1997) brand personality scale. The respondents showed no difficulty in personifying public housing estates and attaching personality traits to them. A total of 70 traits were mentioned by the respondents during the in-depth interviews. All the traits or attributes mentioned by the respondents were consistent with those developed by Aaker (1997) and could be categorized into the 42 traits developed by Aaker (see Table 1). These include small town, leader, cool, trendy, young, exciting, friendly, daring, relevant, intelligent, hardworking, real, honest, independent, secure, family-oriented and reliable. Some dimensions (or factors) of human personality are mirrored in public housing estates, such as happy, active, strong, lively and reliable. Brand personality includes demographic characteristics such as gender, age and class, which include traits like old, young, mature, beautiful, pleasant, pretty, strong and middle-income. Therefore, for the purposes of this research, the dimensions proposed by Aaker (1997) were adopted to investigate the brand personality of public housing estates in Singapore.

\section{DATA ANALYSIS: QUANTITATIVE RESEARCH PHASE}

\section{Mean Ratings of Brand Personality of Public Housing Estates}

Table 2 shows the mean score ratings of the three housing estates under study. None of the three housing estates has an agreeability rating of less than 2 or greater 
than 4, which equates to higher degree of disagreement or agreement to the statements about the personality traits of the housing estates in the questionnaire. This infers that respondents do not have extreme perceptions. Masculine or feminine are not distinct traits in the three housing estates, and therefore in personifying these housing estates, "he/she" and "person" will be used as a general term.

\section{Jurong East Personified}

The mean scores range from the lowest value of 2.19 to the highest of 3.61. "Down to earth" and "family-oriented" have the highest agreeability mean scores of 3.61 and "glamorous" has the lowest mean score of 2.91 .

Personified, Jurong East could be described as a family-oriented, secured, friendly, sincere and honest person. Being located near to the industrial estate, Jurong East's personality would be seen as someone who is successful, confident and has good technical skills. On the other hand, Jurong East is seen as someone who is not glamorous, cool and exciting. Being an old housing estate, it seems to have lost its charm and good looks.

\section{Pasir Ris Personified}

The mean scores range from the lowest value of 2.71 to the highest of 3.79 . The highest and lowest agreeability ratings are relatively higher compared to Jurong East. The trait, "family-oriented" has the highest agreeability mean score with the lowest mean score being "technical".

Pasir Ris's personalities are somewhat different from Jurong East. In addition to being a family-oriented person, Pasir Ris is young, outdoorsy, exciting, trendy, original and unique. He/she is imaginative, spirited, cool, independent and daring.

\section{Sengkang Personified}

The mean scores range from the lowest value of 2.62 to the highest of 3.67. Being among the newer housing estates in Singapore, it is no surprise that the trait "young" has the highest agreeability mean score. The trait "corporate" recorded the lowest agreeability mean score.

Sengkang, being a young person, is one who is up-to-date. There is one side of $\mathrm{him} / \mathrm{her}$, which is similar to Jurong East; real, family-oriented, down-to-earth, sincere, secured, reliable, hardworking and wholesome, although Jurong East recorded relatively higher ratings in these traits. Interestingly, the other side of him/her is like Pasir Ris, one who is daring, trendy, cool, imaginative and original. 
Table 2: Mean rating of Jurong East, Pasir Ris and Sengkang housing estates

\begin{tabular}{|c|c|c|c|}
\hline \multirow[t]{2}{*}{ Brand Personality Traits } & \multicolumn{3}{|c|}{ Mean } \\
\hline & Jurong East & Pasir Ris & Sengkang \\
\hline Down to earth & 3.61 & 3.30 & 3.16 \\
\hline Family-oriented & 3.61 & 3.79 & 3.33 \\
\hline Real & 3.54 & 3.44 & 3.15 \\
\hline Hardworking & 3.48 & 3.07 & 3.00 \\
\hline Secure & 3.43 & 3.28 & 3.04 \\
\hline Reliable & 3.36 & 3.20 & 3.01 \\
\hline Wholesome & 3.35 & 3.49 & 3.00 \\
\hline Independent & 3.33 & 3.49 & 3.17 \\
\hline Technical & 3.26 & 2.71 & 2.82 \\
\hline Successful & 3.19 & 3.36 & 2.90 \\
\hline Sincere & 3.17 & 3.34 & 3.15 \\
\hline Confident & 3.13 & 3.41 & 2.92 \\
\hline Friendly & 3.10 & 3.54 & 2.95 \\
\hline Honest & 3.07 & 3.32 & 3.16 \\
\hline Original & 3.04 & 3.44 & 3.11 \\
\hline Corporate & 3.00 & 2.77 & 2.62 \\
\hline Intelligent & 2.95 & 3.27 & 3.03 \\
\hline Contemporary & 2.92 & 3.47 & 3.20 \\
\hline Cheerful & 2.86 & 3.63 & 2.99 \\
\hline Rugged & 2.86 & 2.84 & 2.67 \\
\hline Tough & 2.85 & 2.85 & 2.68 \\
\hline Leader & 2.84 & 3.12 & 2.74 \\
\hline Up-to-date & 2.74 & 3.52 & 3.42 \\
\hline Spirited & 2.73 & 3.47 & 2.87 \\
\hline Daring & 2.71 & 3.24 & 3.06 \\
\hline Sentimental & 2.69 & 3.10 & 2.78 \\
\hline Masculine & 2.68 & 2.95 & 2.79 \\
\hline Small town & 2.66 & 2.91 & 3.25 \\
\hline Outdoorsy & 2.59 & 3.70 & 2.82 \\
\hline Unique & 2.56 & 3.47 & 3.14 \\
\hline Smooth & 2.55 & 3.05 & 2.81 \\
\hline Exciting & 2.51 & 3.56 & 2.86 \\
\hline Trendy & 2.46 & 3.50 & 3.08 \\
\hline Cool & 2.44 & 3.39 & 3.08 \\
\hline Young & 2.43 & 3.76 & 3.67 \\
\hline Imaginative & 2.41 & 3.47 & 3.01 \\
\hline Charming & 2.40 & 3.26 & 2.85 \\
\hline Good-looking & 2.36 & 3.34 & 3.03 \\
\hline Upper-class & 2.36 & 2.94 & 2.66 \\
\hline Feminine & 2.32 & 2.96 & 2.82 \\
\hline Western & 2.29 & 2.90 & 2.68 \\
\hline Glamorous & 2.19 & 2.89 & 2.69 \\
\hline
\end{tabular}

Pacific Rim Property Research Journal, Vol 10, No 2 
However, as Sengkang is still a very young estate, being built in the late 1990s, the personalities, though similar to that of Jurong East and Pasir Ris, are distinctively not as well developed. There is the potential of him/her emerging as a person, with the combined positive personalities of Pasir Ris and Jurong East as brand personality is created, developed and changed over time.

\section{Factor analysis}

This section illustrates the use of factor analysis via the principal component analysis to group the 42 traits in order to articulate more precisely and clearly the brand personality (BP) of the three housing estates, extending the scope of just basing on the five broad dimensions set by Aaker (1997). In addition, the weighted factor rating (WFR) developed by Ibrahim (2002) will be adopted to translate the factor loadings of each factor into weighted means for clearer interpretation and comparison of the factors produced by the principal component analysis.

In this study, principal component analysis is adopted for two purposes, namely, data reduction and identification of the underlying dimensions or factors associated with the individual respondent's perceptions. Essentially, the procedures of the technique involve a series of iterations, where a set of composite factors is generated, each typically representing a grouping of correlated variables within the original set. Tables 3 to 5 outline the solutions to the principal component analysis of the three housing estates. It lists the variance accounted by the factors, the Bartlett's test of sphericity and Kaiser-Meyer-Olkin (KMO) measure of sampling adequacy. The attributes relevant to each factor are described in the illustration of each factor under each housing estate. The Bartlett's test of sphericity and KMO are adopted to determine the appropriateness of the data set for the principal component analysis (Hair, et al., 1998). This depends on the presence of several reasonable correlations between the variables to be used in the principal component analysis. The Bartlett's test of sphericity examines the hypothesis that the variables are uncorrelated in the population. On the other hand, the KMO is a measure of sampling adequacy to examine the appropriateness of principal component analysis. High values (between 0.5 and 1.0) indicate that principal component analysis is appropriate, while values below 0.5 imply that principal component analysis may not be appropriate. On the other hand, the alpha value indicates the reliability of the attributes to each factor (Cronbach, 1951).

The latent root criterion (eigenvalues greater than one) has been adopted as the main method in extracting the appropriate number of factors, as the number of attributes for each of the housing estate is in the range of 20 to 50 (Hair et al., 1998). The rationale behind this technique is that any individual factor should account for the variance of at least a single variable if it is to be retained for interpretation. Therefore, only factors having eigenvalues greater than 1 are considered significant while those with less than 1 will be considered insignificant and disregarded. 
After the extraction of factors, it is important to look at the factor loading. It is the means of interpreting the role each variable plays in defining each factor. Loadings indicate the degree of correspondence between the variable and the factor, with higher loadings making the variable a better representative of the main factor (Hair et al., 1998). Therefore, the variables with higher loadings are likely to influence the labelling of the factors. However, it should be recognised that these labels are the outcome of subjective interpretation of the researchers.

The values of the Bartlett's test of sphericity and KMO in Tables 3 to 5 indicate the appropriateness of the data of the three housing estates for factor analysis. The latent root criterion (eigenvalues greater than one) suggested a ten-factor solution for Jurong East, eight-factor solution for Pasir Ris and eleven-factor solution for Sengkang. The factor solution for each of the housing estate account for at least $66.35 \%$ of the variance within the original variables of each housing estate. The factor solution for Sengkang recorded the highest variance $(72.28 \%)$ while Pasir Ris recorded the lowest variance $(66.35 \%)$.

Table 3: Latent brand personality dimensions of Jurong East

\begin{tabular}{|l|l|c|}
\hline \multicolumn{1}{|c|}{ Factor } & Brand Personality Traits & Factor Loadings \\
\hline Factor 1:Exciting & Exciting & 0.841 \\
Variance: $13.70 \%$ & Trendy & 0.788 \\
Coefficient Alpha: 0.9059 & Spirited & 0.742 \\
& Cool & 0.671 \\
& Daring & 0.667 \\
& Young & 0.630 \\
& Imaginative & 0.614 \\
& Up-to-date & 0.547 \\
& Contemporary & 0.529 \\
& Cheerful & 0.470 \\
Factor 2:Classy & Glamorous & $0.415^{*}$ \\
Variance: $10.083 \%$ & Friendly & $0.352^{*}$ \\
\hline & Good looking & 0.776 \\
Coefficient Alpha: 0.8774 & Charming & 0.767 \\
& Feminine & 0.712 \\
& Glamorous & 0.700 \\
& Smooth & 0.689 \\
Factor 3:Outstanding & Upper class & 0.598 \\
Variance: $8.628 \%$ & Western & 0.391 \\
\hline Coefficient Alpha: 0.8476 & Corporate & 0.766 \\
& Leader & 0.650 \\
& Successful & 0.634 \\
& Confident & 0.572 \\
& Intelligent & 0.510 \\
\hline
\end{tabular}




\begin{tabular}{|c|c|c|}
\hline & $\begin{array}{l}\text { Technical } \\
\text { Upper class }\end{array}$ & $\begin{array}{c}0.494 \\
0.412 * \\
\end{array}$ \\
\hline \multirow[t]{2}{*}{ Factor 4:Hardworking } & Hardworking & 0.770 \\
\hline & Reliable & 0.750 \\
\hline Variance: $8.039 \%$ & Secure & 0.723 \\
\hline \multirow{5}{*}{ Coefficient Alpha: 0.8375} & Independent & 0.543 \\
\hline & Intelligent & $0.459 *$ \\
\hline & Down-to-earth & 0.448 \\
\hline & Technical & $0.430 *$ \\
\hline & Contemporary & $0.376^{*}$ \\
\hline \multirow[t]{2}{*}{ Factor 5:Rugged } & Rugged & 0.862 \\
\hline & Tough & 0.857 \\
\hline Variance: $6.302 \%$ & Masculine & 0.620 \\
\hline \multirow{2}{*}{ Coefficient Alpha: 0.7990} & Outdoorsy & 0.411 \\
\hline & Technical & $0.373 *$ \\
\hline \multirow[t]{2}{*}{ Factor 6:Warmth } & Sincere & 0.812 \\
\hline & Honest & 0.762 \\
\hline Variance: $5.487 \%$ & Real & 0.424 \\
\hline \multicolumn{3}{|l|}{ Coefficient Alpha: 0.7234} \\
\hline \multirow[t]{2}{*}{ Factor 7:Family-oriented } & Wholesome & 0.684 \\
\hline & Family-oriented & 0.642 \\
\hline Variance: $4.879 \%$ & Down-to-earth & 0.548 \\
\hline \multicolumn{3}{|l|}{ Coefficient Alpha: 0.6919} \\
\hline \multirow{2}{*}{ Factor 8:Expressive } & Sentimental & 0.761 \\
\hline & Original & 0.599 \\
\hline Variance: $5.829 \%$ & Friendly & 0.541 \\
\hline \multicolumn{3}{|l|}{ Coefficient Alpha: 0.7550} \\
\hline \multirow[t]{2}{*}{ Factor 9:Unique } & Unique & 0.768 \\
\hline & Independent & $0.369 *$ \\
\hline Variance: $3.553 \%$ & Up-to-date & $0.541 *$ \\
\hline \multicolumn{3}{|l|}{ Coefficient Alpha:0.6857 } \\
\hline \multirow{2}{*}{ Factor 10:Small } & Small & 0.699 \\
\hline & \multicolumn{2}{|c|}{ Variance: $3.092 \%$} \\
\hline \multicolumn{3}{|l|}{ Coefficient Alpha: 0.0758} \\
\hline \multirow{3}{*}{\multicolumn{2}{|c|}{$\begin{array}{l}\text { Bartlett's Test of Sphericity } \\
\text { Kaiser-Meyer-Olkin Measure of Sampling Adequacy } \\
\text { Total Variance }\end{array}$}} & 0.000 \\
\hline & & 0.862 \\
\hline & & $68.262 \%$ \\
\hline
\end{tabular}

* Denotes an attribute with a higher loading within another factor 
All the housing estates share three common factors, namely "unique", "rugged" and "classy". With reference to Tables 3 to 5 , "unique" is strongly associated with traits, such as original, trendy, unique, independent and contemporary. The factor "rugged" is linked to variables such as outdoorsy, masculine, tough and rugged. "Classy" is associated with variables such as upper-class, glamorous, charming and good-looking.

The factors "hardworking" and "warmth" are common in Jurong East and Sengkang, while the factor "dependable" is common in Pasir Ris and Sengkang. Finally, the factor "exciting" is common in Jurong East and Pasir Ris. The rest of the factors are unique to the specific housing estate. These include "familyoriented", "outstanding" and "expressive" in Jurong East, "sporty" and "charismatic" in Pasir Ris and "young", "vibrant", "pleasant' and "attractive" in Sengkang. The attributes which load in each of these factors are shown in Tables 3 to 5 .

Table 4: Latent brand personality dimensions of Pasir Ris

\begin{tabular}{|l|l|c|}
\hline Factor & Brand Personality Traits & Factor Loadings \\
\hline Factor 1:Exciting & Cool & 0.834 \\
Variance: $13.437 \%$ & Exciting & 0.738 \\
Coefficient Alpha: 0.9132 & Trendy & 0.722 \\
& Spirited & 0.704 \\
& Imaginative & 0.655 \\
& Young & 0.585 \\
& Daring & 0.558 \\
& Upper-class & 0.549 \\
& Up-to-date & $0.514^{*}$ \\
& Glamorous & $0.448^{*}$ \\
& Contemporary & $0.410^{*}$ \\
& Good-looking & $0.381^{*}$ \\
& Unique & $0.378^{*}$ \\
\hline \multirow{3}{*}{ Variance: $12.556 \%$} & Corporate & 0.739 \\
& Hardworking & 0.719 \\
& Technical & 0.702 \\
& Intelligent & 0.655 \\
& Secure & 0.654 \\
& Leader & 0.580 \\
& Reliable & 0.559 \\
& Successful & 0.523 \\
& Smooth & 0.469 \\
& Confident & $0.452^{*}$ \\
& Good-looking & $0.430^{*}$ \\
& Glamorous & $0.413^{*}$ \\
& Feminine & $0.392^{*}$ \\
\hline
\end{tabular}




\begin{tabular}{|c|c|c|}
\hline & $\begin{array}{l}\text { Charming } \\
\text { Honest } \\
\text { Upper-class }\end{array}$ & $\begin{array}{l}0.389 * \\
0.389 * \\
0.373 *\end{array}$ \\
\hline $\begin{array}{l}\text { Factor 3:Dependable } \\
\text { Variance: } 9.816 \% \\
\text { Coefficient Alpha: } 0.8807\end{array}$ & $\begin{array}{l}\text { Down-to-earth } \\
\text { Real } \\
\text { Sincere } \\
\text { Wholesome } \\
\text { Honest } \\
\text { Family-oriented } \\
\text { Original } \\
\text { Reliable } \\
\text { Cheerful }\end{array}$ & $\begin{array}{c}0.725 \\
0.675 \\
0.671 \\
0.637 \\
0.592 \\
0.549 \\
0.466 \\
0.388^{*} \\
0.354^{*}\end{array}$ \\
\hline $\begin{array}{l}\text { Factor 4:Sporty } \\
\text { Variance: } 8.583 \% \\
\text { Coefficient Alpha: } 0.8818\end{array}$ & $\begin{array}{l}\text { Outdoorsy } \\
\text { Cheerful } \\
\text { Friendly } \\
\text { Family-oriented } \\
\text { Confident } \\
\text { Original } \\
\text { Intelligent } \\
\text { Successful }\end{array}$ & $\begin{array}{c}0.725 \\
0.664 \\
0.628 \\
0.500^{*} \\
0.478 \\
0.416^{*} \\
0.398^{*} \\
0.388^{*}\end{array}$ \\
\hline $\begin{array}{l}\text { Factor 5:Rugged } \\
\text { Variance: } 6.895 \% \\
\text { Coefficient Alpha: } 0.8187\end{array}$ & $\begin{array}{l}\text { Tough } \\
\text { Rugged } \\
\text { Masculine } \\
\text { Western }\end{array}$ & $\begin{array}{l}0.862 \\
0.824 \\
0.623 \\
0.574\end{array}$ \\
\hline $\begin{array}{l}\text { Factor 6:Unique } \\
\text { Variance:6.098\% } \\
\text { Coefficient Alpha:0.8338 }\end{array}$ & $\begin{array}{l}\text { Independent } \\
\text { Contemporary } \\
\text { Unique } \\
\text { Up-to-date } \\
\text { Confident } \\
\end{array}$ & $\begin{array}{c}0.647 \\
0.578 \\
0.571 \\
0.537 \\
0.377 * \\
\end{array}$ \\
\hline $\begin{array}{l}\text { Factor } 7: \text { Classy } \\
\text { Variance: } 5.484 \% \\
\text { Coefficient Alpha: } 0.8403\end{array}$ & $\begin{array}{l}\text { Sentimental } \\
\text { Charming } \\
\text { Glamorous } \\
\text { Good-looking } \\
\text { Smooth } \\
\text { Feminine } \\
\end{array}$ & $\begin{array}{c}0.705 \\
0.563 \\
0.542 \\
0.456 \\
0.425^{*} \\
0.411 \\
\end{array}$ \\
\hline $\begin{array}{l}\text { Factor 8:Small } \\
\text { Variance: } 3.482 \% \\
\text { Coefficient Alpha: } 0.1923\end{array}$ & $\begin{array}{l}\text { Small } \\
\text { Leader }\end{array}$ & $\begin{array}{c}0.731 \\
-0.365^{*}\end{array}$ \\
\hline \multicolumn{2}{|c|}{$\begin{array}{l}\text { Bartlett's Test of Sphericity } \\
\text { Kaiser-Meyer-Olkin Measure of Sampling Adequacy } \\
\text { Total Variance }\end{array}$} & $\begin{array}{c}0.000 \\
0.904 \\
66.351 \%\end{array}$ \\
\hline
\end{tabular}

* Denotes an attribute with a higher loading within another factor 
With the exception of the factors "small" in Jurong East and Pasir Ris, the rest of the factors in the factor solutions of the three estates have coefficient alpha values greater than 0.650, thus suggesting that they are reliable (Dawson et. al., 1990). Hence, we may have to drop the factor "small" from subsequent analyses and they have to be treated with caution.

Table 5: Latent brand personality dimensions of Sengkang

\begin{tabular}{|c|c|c|}
\hline Factor & Brand Personality Traits & Factor Loadings \\
\hline \multirow[t]{2}{*}{ Factor 1:Hardworking } & Secure & 0.695 \\
\hline & Hardworking & 0.694 \\
\hline \multirow[t]{2}{*}{ Variance: $9.392 \%$} & Reliable & 0.687 \\
\hline & Confident & 0.596 \\
\hline \multirow[t]{5}{*}{ Coefficient Alpha:0.8942 } & Successful & 0.537 \\
\hline & Intelligent & 0.417 \\
\hline & Smooth & $0.393 *$ \\
\hline & Wholesome & $0.378^{*}$ \\
\hline & Down-to-earth & $0.360 *$ \\
\hline \multirow[t]{2}{*}{ Factor 2:Unique } & Daring & 0.719 \\
\hline & Unique & 0.705 \\
\hline \multirow[t]{2}{*}{ Variance: $9.382 \%$} & Exciting & 0.683 \\
\hline & Trendy & 0.641 \\
\hline \multirow[t]{3}{*}{ Coefficient Alpha:0.8767 } & Imaginative & 0.629 \\
\hline & Original & 0.619 \\
\hline & Good Looking & $0.378^{*}$ \\
\hline \multirow[t]{2}{*}{ Factor 3:Rugged } & Tough & 0.790 \\
\hline & Rugged & 0.753 \\
\hline \multirow[t]{2}{*}{ Variance: $8.050 \%$} & Masculine & 0.692 \\
\hline & Western & 0.690 \\
\hline Coefficient Alpha:0.8293 & Outdoorsy & 0.589 \\
\hline \multirow[t]{2}{*}{ Factor 4:Warmth } & Sincere & 0.784 \\
\hline & Honest & 0.778 \\
\hline \multirow{2}{*}{ Variance: $7.287 \%$} & Real & 0.697 \\
\hline & \multicolumn{2}{|c|}{ Coefficient Alpha:0.8170 } \\
\hline \multirow[t]{2}{*}{ Factor 5:Young } & Young & 0.720 \\
\hline & Up-to-date & 0.714 \\
\hline \multirow[t]{2}{*}{ Variance: $7.253 \%$} & Independent & 0.649 \\
\hline & Contemporary & 0.646 \\
\hline \multirow{2}{*}{$\underline{\text { Coefficient Alpha:0.8456 }}$} & Intelligent & $0.402 *$ \\
\hline & Trendy & $0.394 *$ \\
\hline \multirow[t]{2}{*}{ Factor 6:Attractive } & Feminine & 0.654 \\
\hline & Good-looking & 0.646 \\
\hline \multirow[t]{2}{*}{ Variance: $6.898 \%$} & Charming & 0.636 \\
\hline & Smooth & 0.581 \\
\hline Coefficient Alpha:0.8381 & Glamorous & $0.450 *$ \\
\hline
\end{tabular}

Pacific Rim Property Research Journal, Vol 10, No 2 


\begin{tabular}{|c|c|c|}
\hline $\begin{array}{l}\text { Factor 7:Pleasant } \\
\text { Variance: } 6.072 \% \\
\text { Coefficient Alpha:0.8087 }\end{array}$ & $\begin{array}{l}\text { Sentimental } \\
\text { Cheerful } \\
\text { Friendly } \\
\text { Leader } \\
\text { Real } \\
\end{array}$ & $\begin{array}{c}0.818 \\
0.670 \\
0.627 \\
0.383^{*} \\
0.357^{*} \\
\end{array}$ \\
\hline $\begin{array}{l}\text { Factor 8:Professional } \\
\text { Variance: } 4.997 \% \\
\text { Coefficient Alpha:0.7829 }\end{array}$ & $\begin{array}{l}\text { Technical } \\
\text { Corporate }\end{array}$ & $\begin{array}{l}0.788 \\
0.786\end{array}$ \\
\hline $\begin{array}{l}\text { Factor 9:Dependable } \\
\text { Variance: } 4.750 \% \\
\text { Coefficient Alpha:0.6962 }\end{array}$ & $\begin{array}{l}\text { Small } \\
\text { Down-to-earth } \\
\text { Family-oriented } \\
\text { Wholesome }\end{array}$ & $\begin{array}{l}0.751 \\
0.646 \\
0.528 \\
0.396\end{array}$ \\
\hline $\begin{array}{l}\text { Factor 10:Vibrant } \\
\text { Variance: } 4.533 \% \\
\text { Coefficient Alpha:0.7189 }\end{array}$ & $\begin{array}{l}\text { Spirited } \\
\text { Cool } \\
\text { Friendly }\end{array}$ & $\begin{array}{c}0.741 \\
0.567 \\
0.394^{*}\end{array}$ \\
\hline $\begin{array}{l}\text { Factor 11:Classy } \\
\text { Variance:3.671\% } \\
\text { Coefficient Alpha:0.7842 }\end{array}$ & $\begin{array}{l}\text { Upper-class } \\
\text { Glamorous }\end{array}$ & $\begin{array}{l}0.609 \\
0.530\end{array}$ \\
\hline \multicolumn{2}{|c|}{$\begin{array}{l}\text { Bartlett's Test of Sphericity } \\
\text { Kaiser-Meyer-Olkin Measure of Sampling Adequacy } \\
\text { Total Variance }\end{array}$} & $\begin{array}{c}0.000 \\
0.879 \\
72.285 \%\end{array}$ \\
\hline
\end{tabular}

* Denotes an attribute with a higher loading within another factor

\section{Weighted factor rating}

Table 6 shows the weighted factor ratings (WFR) of the factors produced by the principal component analysis. It aims to show the relative scores of the various factors which shape the brand personality of each public housing estate investigated in this study based on average scores for variables derived from the original survey weighted by the factor loading of the individual variables. The WFR will produce values between 1 to 5 , which are consistent with the scale rating adopted in the questionnaire. It is then easier to express the direction and the magnitude of differences between factors. The WFR is computed as follows (Ibrahim, 2002):

Weighted Factor Rating of Factor ${ }_{k}=\frac{\sum_{j=1} \mu_{j k} f_{j k}}{\sum_{j=1} f_{j k}}$ 
where: $\mu_{\mathrm{jk}}=$ mean score rating of variable $\mathrm{j}$ in factor $\mathrm{k}$

$\mathrm{f}_{\mathrm{jk}}=$ factor loading of variable $\mathrm{j}$ in factor $\mathrm{k}$.

In summary, the respondents perceived Jurong East as family-oriented, hardworking and warmth. However, they have relatively less strong perceptions of Jurong East as outstanding, expressive, unique, rugged, exciting and classy. On the other hand, the respondents perceived Pasir Ris as sporty, unique, dependable, exciting, charismatic and classy. However, Pasir Ris was not perceived as being rugged although its overall score for this trait was higher than the other two housing estates. Finally, the respondents perceived Sengkang as young, dependable, warmth and unique. However, Sengkang scored relatively lower on factors such as, hardworking, rugged, attractive, pleasant, professional, vibrant and classy.

Table 6: Weighted factor ratings for brand personality factors of Jurong East, Pasir Ris and Sengkang

\begin{tabular}{|l|l|l|l|l|l|}
\hline \multicolumn{7}{|c|}{ Factor/weighted factor rating (WFR) } \\
\hline Jurong East & WFR & Pasir Ris & \multicolumn{1}{l|}{ WFR } & \multicolumn{1}{l|}{ Sengkang } & WFR \\
\hline Family-oriented & 3.52 & Sporty & 3.54 & Young & 3.30 \\
Hardworking & 3.32 & Unique & 3.48 & Dependable & 3.20 \\
Warmth & 3.19 & Dependable & 3.43 & Warmth & 3.13 \\
Outstanding & 2.98 & Exciting & 3.40 & Unique & 3.04 \\
Expressive & 2.91 & Charismatic & 3.11 & Hardworking & 2.96 \\
Unique & 2.85 & Classy & 3.10 & Vibrant & 2.96 \\
Rugged & 2.83 & Rugged & 2.88 & Pleasant & 2.91 \\
Exciting & 2.60 & & Attractive & 2.85 \\
Classy & 2.36 & & Rugged & 2.72 \\
& & & Professional & 2.72 \\
& \multicolumn{7}{|l}{} & & Classy & 2.67 \\
\hline
\end{tabular}

\section{CONCLUSIONS}

In conclusion, the three housing estates, all built in different periods, Jurong East in the 1980s, Pasir Ris in the early 1990s and Sengkang in the late 1990s, each has certain personalities that are distinct to them. However, they also share similar traits. In terms of a person, Jurong East is family-oriented, who is warm and hardworking. He/she is not perceived as outstanding, expressive, exciting or classy. Pasir Ris personality is somewhat different. He/she is sporty, unique, charismatic and exciting. Sengkang is a young person. However, he/she is seen as someone who is not particularly attractive, classy, rugged, pleasant or professional. 
Pasir Ris is perceived as a more exciting person than Jurong East. However, both Jurong East and Sengkang are perceived as warm. Jurong East is however, more hardworking than Sengkang. Both Pasir Ris and Sengkang are seen as dependable. Pasir Ris is perceived as classier than the other two housing estates. In terms of uniqueness, Pasir Ris is most unique, followed by Sengkang and then Jurong East. All the three housing estates are not perceived in terms of being a rugged person.

Negative personalities have a disproportionate impact on purchasing (Triplett, 1994). Buyers might not purchase flats in certain housing estates because of the negative personalities that are not congruent with either their own or their sought after ideal personalities (Sirgy, 1982). On the other hand, the properties in a housing estate may be in demand due to its positive "personality". Buyers perceived the brand as a partner in a relationship and brand personality as the set of traits belonging to this partner (Fournier, 1994, 1998). The price paid for a flat may not be at a premium if people are not able to establish an emotional relationship with their potential purchase.

Brand personality might be the only dimensions that differentiate product in a consumer's mind (Triplett, 1994) and a distinctive personality will successfully differentiate a brand (Lannon, 1993). It is therefore worthwhile to continue to manage and develop the character of public housing estates so that their personalities can be made distinctive. For example, between Jurong East and Pasir Ris, there are no distinct differences in terms of toughness and ruggedness. Between Jurong East and Sengkang, there are no distinct differences in sincerity, toughness, leader, spirited, sentimental, masculine and ruggedness. This might be of interest to the planners and town councils as they plan and manage the property. A new town like Pasir Ris, which is distinctively different from Jurong East in traits such as excitement and sophistication, should continue to have its own unique personality. Statutory Boards like Urban Redevelopment Authority (URA) and Housing Development Board (HDB) should continue to manage and plan to maintain and even enhance the distinct personalities. This will help to create certain elements of uniqueness among the different housing estates, which may attract people of different demographics to these estates. As illustrated in this research, the brand personality is different for each of the three housing estates and this has significant implications for different purchasers, in terms of age, gender and social class groups. It is not easy for a housing estate to establish a brand personality that appeals to the mature and middle-income people and at the same time to be appealing to sophisticated and intellectual buyers. For example, Pasir Ris, as "exciting" and "sophisticated", most probably will appeal to people who are young, exciting and daring rather than to the older generation. Therefore, there is a need to identify a target market and then develop a brand personality for the housing estates, which the target market will prefer. One of Pasir Ris' personality traits is charisma. However, with a score of 3.11 , it is still not as distinct and there is a potential in the personality traits as brand loyalty is driven by brands that have a 
charismatic personality (Aaker, 1996). Therefore, efforts should be taken to develop this personality as one of the main distinctive marketing traits for Pasir Ris. Over time, each housing estate will have its own personality which will contribute to the variety of personalities among the different housing estates in Singapore.

By adopting Aaker's (1997) 42-item dimensions in investigating the brand personality of public housing estates in Singapore, this research provides an avenue for town planners, town councillors, as well as estate managers to measure and position the brand personalities of their housing estates, as well as meeting the needs of the residents living in the housing estate. Although the qualitative research findings were consistent with the dimensions adopted by Aaker (1997), we feel that the best way to compile adjectives for measuring brand personality has yet to be fully defined. In particular, it is important that more research work be carried out in the real estate market to refine the dimensions found in this study to enhance our understanding of brand personalities among the real estate products.

\section{REFERENCES}

Aaker, D. (1996) Building Strong Brands. Free Press, New York.

Aaker, L.J. (1997) Dimensions of Brand Personality. Journal of Marketing Research, 34, pp. 347-356.

Alt, M. and Stone, G. (1988) Can A Brand Be Cheeky? Marketing Intelligence and Planning, 4(6), pp. 9-16.

Batra, R., Donald, R. and Dipinder, S. (1993) Brand Equity and Advertising. Lawrence Erlbaum Associates, Hillsdale, NJ.

Belk, R. (1988) Possessions and the Extended Self. Journal of Consumer Research, 15(2), pp 139-168.

Bellenger, D., Earle, S. and Wilbur, W. (1976) The Congruence of Store Image and Self Image. Journal of Retailing, 52, pp.17-32.

Caprara, G., Barbaranelli, C. and Guido. (1998) Personality as Metaphor: Extension of the Psycholexical Hypothesis and the Five Factor Model to Brand and Product Personality Description, in B. English \& A. Olafsson (eds). European Advances in Consumer Research, 3, Association for Consumer Research, Provo, UT.

Cronbach, L.J. (1951) Coefficient Alpha and the Internal Structure of Tests. Psychometrika, 16, pp. 297-334. 
Dawson, S., Bloch, P. and Ridgway, N. (1990) Shopping Motives, Emotional States, and Retail Outcomes. Journal of Retailing, 66(4), pp. 408-427.

Digman, J.M. (1990) Personality Structure: Emergence of the Five-Factor Model. Annual Review of Psychology, 41, pp. 417-440.

Fournier, S. (1994) A Consumer-brand Relationship Framework for Strategy Brand Management. Unpublished $\mathrm{PhD}$ dissertation, University of Florida.

Fournier, S. (1998) Consumer and their Brands: Developing Relationship Theory in Consumer Research. Journal of Consumer Research, 24(4), pp 343-373.

Hair, J.F. Jr, Anderson, R.E., Tatham, R.L. and Black, W.C. (1998) Multivariate Data Analysis, ( $5^{\text {th }}$ edition). New Jersey, Prentice-Hall.

Ibrahim, M.F. (2002) Disaggregating the Travel Components in Shopping Centre Choice: An Agenda for Valuation Practices. Journal of Property Investment and Finance, 20(3), pp. 277-294.

Ibrahim, M.F. and McGoldrick, P.J. (2003) Shopping Choices with Public Transport Options: An Agenda for the $21^{\text {st }}$ Century. Ashgate, Aldershot.

Kassarjian, H.H. (1971) Personality and Consumer Behaviour: A Review. Journal of Marketing Research, 8, pp. 409-418.

Lannon, J. (1993) Asking the Right Questions: What do People Do with Advertising? In Brand Equity and Advertising, David Aaker and Alexander Biel (ed.), Lawrence Erlbaum Associates, Hillsdale, NJ.

Malhotra, N. (1981) A Scale to Measure Self-concepts, Person Concepts and Product Concepts. Journal of Marketing Research, 18(4), pp. 456-464.

Plummer, J. (1984) How Personality Makes a Difference. Journal of Advertising Research, 24(6), pp. 27-35.

Rook, D. (1985) The Ritual Dimension of Consumer Behaviour. Journal of Consumer Research, 12(3), pp. 251-264.

Siguaw, J., Mattila, A. and Austin, J. (1999) The Brand Personality Scale. Cornell Hotel and Restaurant Administration Quarterly, 40(3), pp. 48-55.

Sirgy, J. (1982) Self-concept in Consumer Behaviour: A Critical Review. Journal of Consumer Research, 9(3), pp.287-300. 
Tashakkori, A. and Teddlie, C. (1998) Mixed Methodology: Combining Qualitative and Quantitative Approaches. Sage, Thousand Oaks, California.

Triplett, T. (1994) Brand Personality Must be Managed or It Will Assume a Life of Its Own. Marketing News, 28(10), pp. 9-11.

URA. (2002) Land Use and Urban Design Planning, Singapore. http://www.ura.gov.sg [28 May 2002].

Walker, R. (1985), An Introduction to Applied Qualitative Research. In Applied Qualitative Research, Walker, R. (ed), Gower Publishing Company, Vermount.

Wells, W., Frank J., Andriuli, F. and Stuart, S. (1957) An Adjective Checklist for the Study of Product Personality. Journal of Applied Psychology, 41, pp. 317-319. 